\title{
Articles
}

\section{Education Library 2.0: The Establishment of a Dynamic Multi-Site Liaison Program}

By Ann Dutton Ewbank, Arizona State University

\begin{abstract}
Using a combination of marketing, Web 2.0 tools, videoconferencing, face-to-face instruction and site visits, a library presence including systematic information literacy instruction is embedded into multiple programs at sixteen sites in a growing college of education with nearly 6000 students and over 115 full-time faculty members. As the needs of the students and faculty evolve, the library program responds. This article describes the education library liaison program for Arizona State University's College of Teacher Education and Leadership, including both successes and challenges, within the context of university, college, and library change.
\end{abstract}

\section{Introduction}

Since its establishment in the mid-1980's, a library liaison program has served the College of Teacher Education and Leadership at Arizona State University (ASU). As one of the largest teacher education programs in the state, the college has an enrollment of over 6000 students in undergraduate and post-baccalaureate teacher preparation programs, M.Ed. programs, and an Ed.D. program. These programs are distributed across ASU's four campuses as well as in fourteen school district partnership sites in urban and rural areas of the state. The college recently instituted its first completely online degree program, the M.Ed. and state certification in early childhood education. These programs enroll students from all areas of Arizona as well as out-of-state.

Given the wide range of education programs in CTEL, a traditional, place-bound academic library and librarian liaison to the college cannot meet the needs of all students and faculty. Utilizing marketing techniques and combination of Web 2.0 tools, teleconferencing, face-toface instruction and site visits, a library presence including systematic information literacy instruction is embedded into each program. The library program encounters unique challenges, particularly within the programs that are geographically distant, as well as within the $100 \%$ online degree program. This article describes the establishment of the library program on multiple campuses and sites, and discusses successes, challenges and future directions.

\section{Review of the Literature}

Library liaison programs in academic settings. The concept of library service delivery through an embedded or liaison model has been taken up by researchers and practitioners in recent years (Attebury \& Holder, 2008; Isaacson, 2001; Konata \& Thaxton, 2001; Smith \&
Sutton, 2008; Stoddart, Bryant, \& Baker, 2006).

Embedded or liaison librarianship has been discussed as an element of service to education schools and colleges through collection development (Ganesh, 2003; Hirsch, 2008; Osa \& Musser, 2004) and instruction and faculty collaboration (Bushong \& Buff, 2008; Floyd, Colvin, \& Bodur, 2008) and also in support of diverse disciplines (Hall, 2008; Tennant \& Cataldo, 2002). Liaison librarianship is used in instructional settings (Christensen, 1994; Hall, 2008; Hearn, 2005; Owens, 2008; Risser, White, \& Benson, 2000), within the context of faculty relationships (Bartnik, 2007; Cataldo, Tennant, \& Sherwill-Navarro, 2006; Chan, 2006; Dewey, 2004; Greever, 1999; Issacson, 2001), and to the university as a whole in areas such as curriculum development (Francis \& Fisher, 1997) outreach (Rudin, 2008) and student affairs (Forrest, 2005; Love, 2007). A common thread uniting these perspectives is that of proactive strategies in order to provide service models that expand into the academic unit-either through instruction, reference and research support, marketing or active participation in academic planning.

Technology solutions for liaison librarianship. A more recent development in liaison librarianship is the advent of technology solutions in order to provide scalable, "just in time" library services to both students and faculty. Due to the proliferation of social media, these technology solutions are mechanisms for further embedding library services into academic departments. Innovations such as subject librarian-specific chat (Gordon \& Stephens, 2007; Marcus, 2007; Northrup. 2008), librarians embedded in course management software for hybrid or $100 \%$ online courses (Karplus, 2006; Stewart, 2007; York \& Vance, 2009) and librarians using 2.0 tools such as podcasts, wikis and RSS feeds (Huffman, 2006) have emerged as ways that 
librarians can extend their reach beyond the four walls of the library and into academic programs.

\section{The College of Teacher Education and Leadership at ASU}

The College of Teacher Education and Leadership (CTEL) was established in the mid-1980s at Arizona State University's West campus. Intended to serve the western portion of metropolitan Phoenix (the much larger Tempe campus and a separate College of Education served the eastern portion), CTEL has experienced dynamic growth over the past eight years. A recent reorganization (Des Georges, 2009) placed all Arizona State University teacher preparation programs under the auspices of CTEL. Presently, CTEL enrolls nearly 6000 students and employs over 115 full-time faculty. CTEL administers campus-based teacher education, M.Ed. and Ed.D. programs on all of ASU's four campuses. The College of Education on the Tempe campus, reorganized as the Fulton Institute and Graduate School of Education, offers education research degrees and Ph.D. programs, and engages in education research. Additionally, CTEL operates Professional Development Schools (PDS) in partner districts around the states. Funded by multiple U.S. Department of Education grants, the degree programs at PDS sites feature teacher preparation courses as well as embedded internship experiences in both urban and rural areas. These programs include baccalaureate and post-baccalaureate teacher preparation programs in elementary, secondary, and special education. A recent addition to distance offerings is educational administration. The U.S. Department of Education awarded CTEL a grant to prepare school administrators in rural and urban areas. Titled URBAN-EXCEL, the program uses videoconferencing to connect future principals in school administration coursework across the state (Des Georges, 2008).

Figure 1. Location of College of Teacher Education and Leadership programs

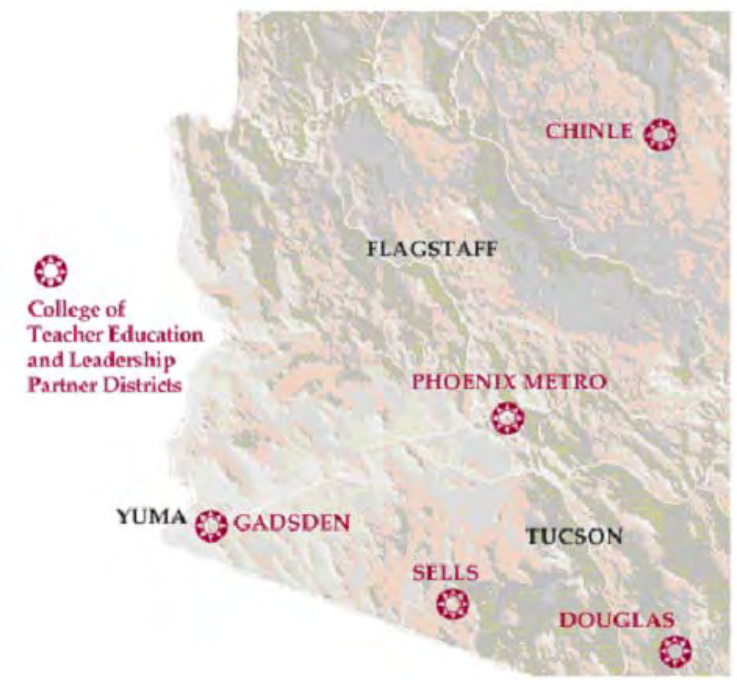

Image credit: http://ctel.asu.edu/community/pds/ 
Table 1. Locations of College of Teacher Education and Leadership Programs

\begin{tabular}{|l|l|}
\hline CTEL Program Location & Degree(s) and Program(s) offered \\
\hline West campus & B.S.Ed., M.Ed, Ed.D. \\
\hline Downtown Phoenix campus & B.S. Ed., M.Ed. \\
\hline Tempe campus & B.S. Ed., M.Ed. \\
\hline Polytechnic campus & B.S. Ed., M.Ed. \\
\hline $100 \%$ Online & M.Ed. \\
\hline Madison (central Phoenix) & B.S. Ed., M.Ed. \\
\hline Osborn (central Phoenix) & M.Ed., Principal Certificate \\
\hline Creighton (central Phoenix) & Principal Certificate \\
\hline Roosevelt (central Phoenix) & Principal Certificate \\
\hline Pendergast (west Phoenix) & B.S. Ed. \\
\hline Avondale (west Phoenix) & B.S. Ed., M.Ed. \\
\hline Deer Valley (north Phoenix) & M.Ed. \\
\hline Paradise Valley (north Phoenix) & B.S. Ed. \\
\hline Chinle (Navajo Nation in NE Arizona) & B.S. Ed., M.Ed., Principal Certificate \\
\hline $\begin{array}{l}\text { Indian Oasis (Tohono O’Odham } \\
\text { reservation in SE Arizona) }\end{array}$ & B.S. Ed., M.Ed., Principal Certificate \\
\hline Gadsden (SW Arizona) & B.S. Ed., M.Ed., Principal Certificate \\
\hline Kingman (NW Arizona) & Principal Certificate \\
\hline Douglas (SE Arizona) & B.S. Ed., M.Ed., Principal Certificate \\
\hline Coolidge (Central Arizona) & Principal Certificate \\
\hline
\end{tabular}

\section{A Dynamic Library Presence}

The traditional bricks-and-mortar library does not meet the needs of a distributed college (Ryckman, Long, \& Yedinak, 2009). Students and faculty must rely on extensive technologies in order to access information. To further complicate matters, ASU Libraries provides hundreds of databases and online collections of materials that are sometimes not easy to navigate, and often overlooked by students in the age of Google. Libraries and librarians constantly battle against disintermediation, where users bypass subscription collections in favor of freely available internet sources (Grossman, 2006). Therefore, the first step in creating a dynamic library presence across all sites and programs is to market services and collections to both faculty and students.

\section{Marketing the Education Library Liaison Program}

Marketing education library liaison programs is an ongoing process. Multiple strategies can be employed in order to successfully market a library liaison program (Petruzzelli, 2005). A centerpiece of marketing ASU's education library liaison program is to disseminate the services to the coordinators at each site and within each degree program. The librarian accomplishes this through a variety of avenues:

- Attendance at orientations and faculty meetings- Site coordinators are required to attend monthly faculty meetings and a campus-based orientation upon hire. The librarian has dedicated time for a library orientation for new hires and attends all faculty meetings.

- Quarterly Newsletter- The librarian sends, via listserv, a quarterly newsletter to all faculty and staff. The newsletter describes ways that the library supports the college, and often highlights accomplishments at remote sites.

- Library Liaison Program Flyer- The librarian disseminates a one page flyer at the beginning of each fall semester that contains contact information, web links to vital services, and a "top 5 resources for students and faculty" list (see Appendix 1).

- One minute video- In order to personalize service, a short video profiling the librarian is available, especially for the students and faculty who may never meet the librarian in person

(http://www.youtube.com/watch?v=qbg xPuz2UQ ).

Marketing is a continuous, ongoing element of the library liaison program. While the librarian has been successful at reaching a core group of faculty over the past three years, student turnover and addition of new faculty each academic year necessitates ongoing 
marketing strategies. Examples of continuous marketing include a new faculty orientation each fall; attendance at the college's new student orientation at the beginning of each semester; distribution of an updated flyer each fall to all faculty; and embedding library instruction in a specific course each semester.

\section{Embedding Information Literacy Instruction}

One of the most challenging parts of the library liaison program is determining how to embed information literacy instruction across such a wide variety of programs at multiple sites. Both distance and on-campus teacher preparation programs are organized by cohort. Students take courses in sequence throughout the program. In order to maximize student and librarian time, the librarian provides instruction in one of the required courses in the first semester, Child and Adolescent Development. Through this course, foundational concepts and skills are taught, such as the concepts of empirical research, peer-review, and advanced searching in ERIC. The concepts taught by the librarian are related to a "signature assignment" in the course, a literature review, so that they are not taught in isolation. Through this arrangement, the librarian is able to make contact with each campus-based student in their first semester and provide them with a solid foundation in education research.

One of the challenges of embedding information literacy instruction is the turnover of instructors for the targeted course, Child and Adolescent Development. In recent semesters, the course has been taught increasingly by part-time adjunct faculty. In an absence of a student information literacy requirement by the college or university, information literacy instruction is negotiated between the faculty member and the librarian. Therefore, the process of relationship-building is ongoing between new faculty and the librarian. Table 2 indicates the number of instruction sessions over the past several academic years.

Table 2. Instruction sessions per academic year.

\begin{tabular}{|l|l|l|}
\hline Academic Year & Instruction Sessions & $\begin{array}{l}\text { Number of Students Receiving } \\
\text { Instruction }\end{array}$ \\
\hline $2006-2007$ & 51 & 1052 \\
\hline $2007-2008$ & 70 & 1394 \\
\hline $2008-2009 *$ & 55 & 1192 \\
\hline
\end{tabular}

*In spring 2009, ASU instituted mandatory furloughs for all employees, and consequently fewer courses were taught.

Professional development school (PDS) sites. Because of their geographic locations, it is not possible for the librarian to teach face-to-face at each PDS, although and face-to-face instruction is provided on request to the Phoenix-based PDS sites. In order to accommodate information literacy instruction at the remote PDS sites, a series of online tutorials are promoted and disseminated. The tutorials include the explanation of concepts such as peer-review and empirical research (http://lib.asu.edu/tutorials).

Additionally, PDS course instruction is conducted via a Distance Learning Studio. This two-way videoconferencing studio connects campus-based instructors with the PDS sites around the state. The Distance Learning Studio allows for lecture delivery, question and answer between sites and instructor, and push technology, allowing students to see web site demonstrations and course materials. The librarian regularly teaches information literacy sessions in the videoconferencing studio. The Distance Learning Studio was the recent recipient of an award for technology innovation (Des Georges, 2007).

\section{Reference and Research Support}

Reference and research support for students and faculty are provided through both traditional and electronic means. Students and faculty utilize email, telephone, and face-to-face appointments to interact with the librarian. In 2008-2009 student consultations increased dramatically over the previous year, while faculty consultations increased slightly (see Table 3).

Table 3. Reference and research support consultations, by academic year.

\begin{tabular}{|l|l|l|}
\hline Academic Year & Student Consultations & Faculty Consultations \\
\hline $2006-2007$ & 119 & 66 \\
\hline $2007-2008$ & 88 & 84 \\
\hline $2008-2009$ & 155 & 88 \\
\hline
\end{tabular}


A recent addition to the tools available for reference and research support at ASU Libraries is LibGuides, a customizable, Web 2.0 library reference application (Springshare, 2009). The ASU Libraries purchased a subscription to LibGuides in late 2007, and the LibGuide for CTEL (http://libguides.asu.edu/education) was established in spring 2008. During 2008, the CTEL LibGuide received over 13,000 hits.

The CTEL LibGuide directs the user to specific library and web resources pertinent to education. Course pages are created in order to support specific courses and assignments upon request. An additional feature of the LibGuide is a Meebo (2009) chat widget. The Meebo widget allows education students and faculty to chat with the education liaison librarian in real time. Meebo widgets have gained popularity in recent years for liaison librarian chat service (Gordon \& Stephens, 2007).

\section{Challenges and Opportunities}

The unique nature of a large, distributed program creates multiple challenges. Students and faculty experience some barriers in locating, identifying, and receiving information and services from ASU Libraries. As in any institution, bureaucratic and political factors impact the development of the education library liaison program. These challenges include:

- Lack of information literacy instruction requirement- Arizona State University has no formal requirement for systematic information literacy instruction. Therefore, librarians must negotiate library lessons with course instructors. Additionally, there is no formal assessment of student information competence. Librarians must rely on the cooperation of faculty in order to reach all students.

- Difficulty in obtaining information about courses and instructors- A large college of education, with multiple sites, administrators, and course schedulers creates difficulty in obtaining information about courses and programs. The librarian spends a significant amount of time researching programs and courses in order to proactively offer library instruction.

- Insufficient library staff to cover all programs Currently, there are three librarians who are assigned to education as a subject specialty. One is the sole librarian for a campus of over 9000 students, and a second covers education as well as all undergraduate core instruction on another campus of approximately 9000 students. The author is the only librarian in the ASU Libraries that has education as her primary subject assignment. More librarians are needed to effectively serve education at Arizona State University.

- Challenges in obtaining physical materials at distance sites and in 100\% online programsThere is no mechanism for students and faculty in distance and online programs to obtain physical materials. ASU Libraries does not support a "books by mail” program. Students and faculty must rely on interlibrary loan from their local public library in order to receive books and other print materials from their university library. Additionally, although ASU Libraries has tens of thousands of full-text electronic journals, students cannot obtain electronic copies of many print journals. A task force is studying this issue, but current economic conditions prevent this service from being implemented.

Assessing the Library Program. In order to determine the most impactful way to deliver services to such a distributed college, several assessments are planned. Because the librarian has had varying degrees of success with embedding the library liaison program at PDS sites, a systematic assessment of access to library services and information at each site has been proposed. The assessment (see Appendix 2) is based on the Standards for Distance Learning Library Services (Association of College and Reference Librarians, 2008) and will be conducted in fall 2009. The assessment will reveal strengths and weaknesses in order to improve the library liaison program. Additional program assessments will be planned and implemented as the newly reorganized college takes shape over the 2009-2010 academic year. A review of off-campus and online syllabi and a survey of distance and off campus faculty could be a possible method of assessment (Ryckman, Long, \& Yedinak, 2009).

\section{Conclusion}

The recent major academic reorganization at Arizona State University, which places all teacher preparation programs at the university under the direction of the College of Teacher Education and Leadership (Des Georges, 2009) is an additional challenge. This arrangement includes the addition of two campus teacher preparation programs to CTEL's existing sixteen locations and one online degree program. The 
reorganization effectively doubles the number of students and faculty in CTEL.

ASU Libraries will be challenged to offer seamless service to all teacher education students and faculty, through the reorganization of education liaison librarians at each of the four campuses, who currently operate autonomously. New configurations, staffing models, and programs will need to be implemented in order to successfully support the college.

The education library liaison program for the College of Teacher Education and Leadership is dynamic, responsive, and is undergoing a significant amount of growth and change. Equipping future teachers with the information competence that they will need in order to be academically successful is the program's primary goal. Whatever challenges the future brings are also opportunities to significantly impact the quality of teacher education in Arizona.

\section{References}

Association of College and Reference Librarians (2008). Standards for distance learning library services. Retrieved February 1, 2009, from http://www.ala.org/ala/mgrps/divs/acrl/standards/guidelin esdistancelearning.cfm

Attebury, R., \& Holder, S. (2008). New liaison librarians: Factors influencing confidence levels and the type of activities undertaken. E-JASL: The Electronic Journal of Academic and Special Librarianship,9(3). Retrieved from http://southernlibrarianship.icaap.org/content/v09n03/atte bury r01.html

Bartnik, L. (2007). The embedded academic librarian: The subject specialist moves into the discipline college. Kentucky Libraries, 71(3), 4-9.

Bushong, S. \& Buff, C. (2008). Information literacy for teaching and learning: A course for teacher practitioners. Education Libraries, 31(2), 12-18.

Cataldo, T. T., Tennant, M. R., \& Sherwill-Navarro, P. (2006). Subject specialization in a liaison librarian program. Journal of the Medical Library Association, 94(4), 446448.

Chan, G. (2006). Customizing faculty's needs: Development of a liaison program (A subject librarian's priority). Charleston conference proceedings 2005. (pp. 103-110) Westport, CT: Libraries Unlimited.

Christensen, P. G. (1994). Using English department library liaisons in a term paper clinic: Reviving the scholar/librarian model. Research Strategies, 12, 196-208.

Des Georges, S. (2009). "College of Teacher Ed to lead ASU teacher prep programs.” ASU News. Retrieved February 1, 2009, from http://asunews.asu.edu/20090127_teacherprep

Des Georges, S. (2008). “Training program nets $\$ 3.7$ million grant.” ASU News. Retrieved February 1, 2009, from http://asunews.asu.edu/node/4522 .

Des Georges, S. (2007). “College of Teacher Education and Leadership presented with Rich Media Impact Scholastic
Achievement Award.” ASU News. Retrieved February 1, 2009, from http://asunews.asu.edu/node/1417 .

Dewey, B. I. (2004). The embedded librarian: Strategic campus collaborations. Resource Sharing and Information Networks, 17(1/2), 5-17.

Floyd, D. M., Colvin, G., \& Bodur, Y. (2008). A facultylibrarian collaboration for developing information literacy skills among preservice teachers. Teaching and Teacher Education: An International Journal of Research and Studies, 24(2), 368-376.

Forrest, L. U. (2005). Academic librarians and student affairs professionals: An ethical collaboration for higher education. Education Libraries, 28(1), 11-15.

Francis, B. W., \& Fisher, C. C. (1997). Librarians as liaisons to college curriculum committees. Medical Reference Services Quarterly, 16, 69-74.

Ganesh, T. G. (2003). Ejournals in education: Just generating excitement or living up to the promise? Education Libraries, 26(1), 5-15.

Gordon, R. S., \& Stephens, M. (2007). Embedding a librarian in your web site using Meebo. Computers in Libraries, 27(8), 44-45.

Greever, K. E. (1999). Building bridges: Moving from the back room to the front line. Catholic Library World, 70(1), 23-26.

Grossman, D. (2006). A lesson from Portugal, or fighting disintermediation. Searcher, 14(4), 45-47.

Hall, R. A. (2008). The "embedded" librarian in a freshman speech class: Information literacy instruction in action. College \& Research Libraries News, 69(1), 28-30.

Hearn, M. R. (2005). Embedding a librarian in the classroom: An intensive information literacy model. Reference Services Review, 33(2), 219-227.

Hirsch, E. G. (2008). "You have kids' books?!" Promoting children's literature in an academic library. Education Libraries, 31(1), 13-16.

Huffman, K. (2006). Web 2.0: Beyond the concept: Practical ways to implement RSS, podcasts, and wikis. Education Libraries, 29(1), 12-19.

Isaacson, D. (2001). Librarians who lunch: Liaisons with new faculty. College \& Research Libraries News, 62(5), 532533.

Karplus, S. S. (2006). Integrating academic library resources and learning management systems: The library Blackboard site. Education Libraries, 29(1), 5-11.

Konata, L. L., \& Thaxton, L. (2001). Transition to a liaison model: Teaching faculty and librarian perceptions. Urban Library Journal, 11(1), 28-56.

Love, E. (2007). Building bridges: Cultivating partnerships between libraries and minority student services. Education Libraries, 30(1), 13-19.

Marcus, S. (2007). Why IM me? I'm right here! Education Libraries, 30(2), 27-29.

Meebo (2009). About Meebo. Retrieved April 27, 2009, from http://www.meebo.com/about/

Northrup, L. (2008). "MeeboMe!" for embedded chat reference: Patron-initiated encounters without downloads or accounts. College \& Undergraduate Libraries, 15(3), 357-363. 
Osa, J. O., \& Musser, L. R. (2004). The role of posters in teacher education programs. Education Libraries, 27(1), 16-21.

Owens, R. (2008). Where the students are: The embedded librarian project at Daytona Beach College. Florida Libraries, 51(1), 8-10.

Petruzzelli, B. (Ed.) (2005). Real-life marketing and promotion strategies in college libraries:

Connecting with campus and community. Binghamton, NY: Haworth Information Press.

Risser, I. K., White, M., \& Benson, G. (2000). The successful liaison program: Librarians and classroom faculty as partners in the instructional process. Against the Grain, 12(5), 22-24.

Rudin, P. (2008). No fixed address: The evolution of outreach library services on university campuses. The Reference Librarian, 49(1), 55-75.

Ryckman, B., Long, V., \& Yedinak, E. (2009). Establishing a baseline: History, evolution and evaluation of Grand Valley State University's off-campus library services. Journal of Library Administration, 49(1/2), 75-88.
Smith, S. S., \& Sutton, L. (2008). Embedded librarians: On the road in the deep south. College \& Research Libraries News, 69(2), 71-4, 85.

Springshare (2009). “ LibGuides.” Retrieved February 1, 2009, from http://www.springshare.com/libguides/ .

Stewart, V. D. (2007). Embedded in the blackboard jungle: The embedded librarian program at Pulaski Technical College. Arkansas Libraries, 64(3), 29-32.

Stoddart, R. A., Bryant, T. W., \& Baker, A. L. (2006). Going boldly beyond the reference desk: Practical advice and learning plans for new reference librarians performing liaison work. The Journal of Academic Librarianship, 32(4), 419-427.

Tennant, M. R., \& Cataldo, T. T. (2002). Development and assessment of specialized liaison librarian services: Clinical vs. basic science in a veterinary medicine setting. Medical Reference Services Quarterly, 21(2), 21-37.

York, A. \& Vance, J. (2009). Taking library instruction into the online classroom: Best practices for embedded librarians. Journal of Library Administration, 49(1/2), 197-209. 


\section{Mission}

The ASU Libraries are settings, both virtual and physical, in which to uncover, discover and learn. We provide seamless access to collections and services for students, faculty, ASU's partners, and the community to promote the New American University's goals of access, excellence, and impact. Our service-oriented staffs support virtual and physical environments that assure access to data, information, and knowledge resources, and strive to foster information competence and critical thinking skills.

Fletcher Library Home Page

http://lib.asu.edu/fletcher

Services for Students

http://lib.asu.edu/services/students

ASU Library Catalog

(Identify books, video/dvd, etc.)

http://library.lib.asu.edu/

\section{DOCUMENT DELIVERY}

To request digital copies of materials owned in paper or microfiche by other ASU libraries:

https://illiad.lib.asu.edu/illiad/Logon.html

To request materials and articles not owned by ASU Libraries:

https://illiad.lib.asu.edu/illiad/Logon.html

YOUR LIBRARIAN:

Ann Ewbank, Ph.D.

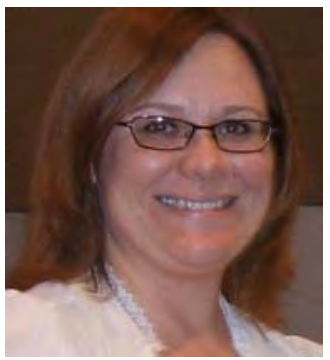

Ann.Ewbank@asu.edu (602) 543-8527

Office: Fletcher Library, 301A

\section{ATTENTION EDUCATION STUDENTS!}

Students in the College of Teacher Education and Leadership receive support from a dedicated library liaison program.

Do you need help...

Getting started with research?

Formatting a bibliography?

Finding articles?

Email or call me! I am a specialist in library resources for education students and have ten years of classroom teaching experience. I can help you with finding the right information for your assignment by using the library's resources.

\section{Top 5 Resources for Students}

1. LibGuides-All of your education resources in one place. Bookmark http://libguides.asu.edu/education on your computer.

2. $33,000+$ Full text journals and 300 online databases. You don't have to come to the library- the library comes to YOU!

3. Get /t ASU - This button lets you know where and how to obtain articles found in our databases, either online or in print. The "Get it" button is seen as databases are searched. It is also available in RefWorks.

4. RefWorks - (http://www.asu.edu/refworks) - an online tool for managing bibliographic citations. Keep a running list of your citations and format custom bibliographies in APA style.

5. In-Depth Research Consultations- I am available to assist you with your research needs in person, by phone or email. Most emails are returned within one business day. 
Appendix 2.

\section{Professional Development School Site Library Assessment Instrument}

Based on Association of College and Reference Librarians' Standards for distance learning library services. http://www.ala.org/ala/mgrps/divs/acrl/standards/guidelinesdistancelearning.cfm

Objective: Gather data through interview(s) with on-site ASU faculty and program managers, and assessment of onsite equipment and networks.

\section{Interview questions:}

\section{Resources:}

1. Do students have sufficient access to information to fulfill course assignments? Specifically, is their access to books, scholarly and professional journal articles, curriculum materials, and appropriate web sites sufficient? If not, what specific resources do students need for successful completion of course assignments?

2. Do faculty and affiliates have sufficient access to information for research needs? Specifically, is their access to books, scholarly and professional journal articles, curriculum materials, and appropriate web sites sufficient? If not, what specific resources do faculty need for research?

3. Do faculty and affiliates have sufficient access to information for course planning and delivery? Specifically, is their access to books, scholarly and professional journal articles, curriculum materials, and appropriate web sites sufficient? If not, what specific resources do faculty need for course planning and delivery?

4. What are the levels of technological access for students and faculty? Do they have sufficient access to equipment and bandwidth in order to access information? Are there issues with firewalls or web filters that impede access to resources? Include all locations where students and faculty might need access (program site, work, home, etc.).

5. What is your experience with access specific to resources obtained from ASU Libraries? Have you been able to obtain resources necessary for your work? Are there any specific barriers you have encountered when attempting to obtain access to ASU Libraries resources?

\section{Services:}

1. Do students and faculty have sufficient access to reference assistance from ASU Libraries, through chat, email or telephone? How often do you estimate that reference assistance is utilized? Are there other ways that ASU Libraries could deliver reference assistance?

2. Do students and faculty have sufficient access to online instructional and informational services, such as the library web site or through the various online subject guides offered? Are additional instruction services needed? How do you prefer that instruction be delivered (e.g., in-person, through the distance learning studio, online modules)?

3. Do students have adequate information literacy skills (are they able to find and use information effectively)?

4. Are students and faculty able to access reciprocal or contractual borrowing, or interlibrary loan services in your community? Through what agencies do you utilize these services? If you do not utilize these types of services, would they be of use to you?

5. Do faculty and students utilize library reserve materials in either electronic or physical format? Are these services adequate for your needs? If not, would you utilize reserve services for your courses?

6. Are the library's service hours adequate for student and faculty needs? Are email, chat, and telephone access to service adequate?

7. Are faculty and students aware of library services to your program, including documented and updated policies, regulations and procedures? 
8. Are students and faculty able to receive prompt delivery of items obtained from ASU Libraries' collections, or through interlibrary loan agreement via courier or electronic delivery system?

9. Are students and faculty able to receive "point of need" assistance with and instruction in the use of library resources? If not, would this type of assistance be helpful?

\section{Assessment of on-site equipment and networks}

1. Inspect on-site locations for the following: computing capabilities (including memory, software, browser compatibility, ability to install plug-ins, etc.); ability to access ASU Libraries’ online resources.

2. Contact network administrator to determine the following: web filter and network permissions, firewall permissions, installation of plug-ins on networked machines, etc.

\section{Data Analysis}

Data will be analyzed utilizing qualitative methods that identify themes and patterns in the following areas: a) access to library resources; b) access to library services.

\section{Dissemination}

A report containing the results of the site-based assessment will be disseminated to CTEL Assistant Dean for Partnerships, and appropriate ASU Libraries workgroups and administrators.

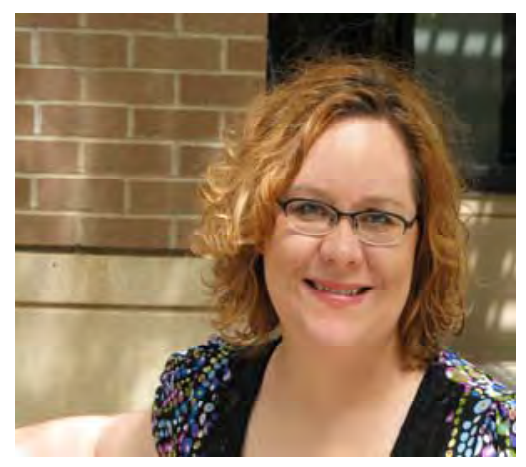

Ann Dutton Ewbank

Arizona State University

Fletcher Library

P.O. Box 37100

Phoenix, AZ

85069-7100

Voice: 602.543 .8527

Fax: 602.543.6500

ann.ewbank@asu.edu 